\title{
Pelaksanaan Kewajiban Pihak Pengembang dalam Pembangunan Perumahan di Desa Fajar Baru Lampung Selatan
}

\author{
M. Lutfi( ${ }^{(1)^{*}}$, Idham ${ }^{(2)}$ Januri( $^{(3)}$, Rendy Renaldy(4) \\ ${ }^{(1)}$ Universitas Sang Bumi Ruwa Jurai, ${ }^{(2)}$ Universitas Sang Bumi Ruwa Jurai, ${ }^{(3)}$ Universitas Sang Bumi Ruwa \\ Jurai, ${ }^{(4)}$ Universitas Sang Bumi Ruwa Jurai \\ email korespondensi:m.lutfi1964@ gmail.com ${ }^{I^{*}}$
}

\begin{abstract}
Abstrak.
Pada dasarnya pembangunan dilaksanakan secara berencana, bertahap serta terarah dan berwawasan lingkungan. Salah satu bagian dari pembangunan nasional di bidang perumahan ini tidak hanya menjadi tanggung jawab pemerintah semata-mata, melainkan tanggung jab semua pihak, baik itu masyarakat, pihak swasta atau dalam hal ini disebut Pihak Pengembang atau Real Estate, dalam hal ini Koperasi Karyawan Pekerjaan Umum Propinsi Lampung disingkat Kokapu. Pembangunan perumahan dipandang dari perspektif ekonomi sebagai sektor unggulan (leading sector) karena memiliki implikasi luas baik dilihat dari sifat multiplier effect (efek gandanya) maupun trickle down effect (dampak tetesan kebawahnya). Pembangunan perumahan ditinjau dari sisi hukum, betujuan untuk menjamin kepastian, ketertiban, keadilan hukum, sehingga pembangunan perumahan haruslah berpedoman pada peraturan hukum yang baerlaku, seperti Undang-Undang Nomor 23 Tahuin 1997 tentang Pengelolaan Lingkungan Hidup, Undang-Undang Nomor 4 Tahun 1992 tentang Perumahan maupun Permukiman maupun peraturan pelaksanaannya. Permasalahan dalam penelitian ini adalah pelaksanaan kewajiban Pihak Pengembang, alasan tidak memenuhi target serta manfaat dalam pembangunan perumahan RSS Fajar Baru Indah Lampung Selatan. Pelaksanaan kewajiban pihak Pengembang dalam pembangunan perumahan RSS Fajar Baru Indah adalah telah membangun unit-unit rumah berjumlah 139 unit rumah, tetapitersebut belum memenuhi persyaratan teknis dan ekologis yang sesuai dengan hukum yang berlaku, belum melakukan pembangunan fasilitas dan sarana umum. Alasannya terbatasnya fasilitas dana KPR BTN dan modal yang tersedia, calon peminat pembeli perumahan terbatas; Manfaatnya yaitu menimbulkan dampak positif yang merupakan manfaat dan keuntungan bagi kehidupan sosial, ekonomi dan budaya. Hendaknya bagi masyarakat yang ingin membeli perumahan terlebih dahulu melakukan survey dan perlu mendapat kepastian hukum dalam membuat perjanjiannya;Pihak Pemerintah yang berwenang mengawasi pihak Pengembang yang membangun perumahan tidak sesuai atau melanggar ketentuan-ketentuan hukum yang berlaku diberikan sangsi yang tegas seperti pencabutan izin; Pihak Perbankan hendaknya perlu memberikan fasilitas kredit perumahan bagi masyarakat golongan kecil, bahkan bunga kreditnya sebaiknya ditanggung oleh pemerintah atau negara.
\end{abstract}

Kata Kunci: Pihak Pengembang Perumahan, Pembangunan Perumahan, Kewajiban Pihak Pengembang

\begin{abstract}
.
Basically, development is carried out in a planned, gradual, directed and environmentally friendly manner. One part of national development in the housing sector is not only the responsibility of the government alone, but the responsibility of all parties, be it the community, the private sector or in this case called the Developer or Real Estate, in this case the Public Works Employee Cooperative. Lampung Province is abbreviated as Kokapu. Housing development is seen from an economic perspective as a leading sector because it has broad implications, both in terms of the nature of the multiplier effect and trickle down effect. Housing development in terms of law, aims to ensure certainty, order, legal justice, so that housing development must be guided by applicable legal regulations, such as Law No. 23/1997 on Environmental Management, Law No. 4/1992 on Housing. as well as Settlements and their implementing regulations. The problem in this study is the implementation of the obligations of the Developer, the reasons for not meeting the target and the benefits in the construction of the Fajar Baru Indah housing complex, South Lampung. The implementation of the obligations of the Developer in the construction of RSS Fajar Baru Indah housing is to have built housing units totaling 139 housing units, but these have not met the technical and ecological requirements in accordance with applicable law, have not carried out the construction of public facilities and facilities. The reason is the limited facilities of KPR BTN funds and available capital, limited potential buyers of housing; The benefit is that it creates a positive impact which is a benefit and advantage for social, economic and cultural life. People who want to buy housing should first conduct a survey and need to get legal certainty in making the agreement; The Government who is authorized to supervise the Developer who builds housing that is not in accordance with or violates the applicable legal provisions is given strict sanctions such as revocation of permits; Banks should provide housing credit facilities for small groups of people, even the interest on loans should be borne by the government or the state.
\end{abstract}




\section{PENDAHULUAN}

Pada dasarnya pembangunan yang dilaksanakan oleh Negara Indonesia adalah pembangungunan berencana, bertahap serta terarah untuk mencapai tujuan dari pada suatu negara, yaitu mewujudkan masyarakat adil dan makmur. Ini berarti hakekat pembangunan nasional adalah pembangunan manusia Indoesia seutuhnya dan pembangunan masyarakat Indonesia berdasarkan Pancasila dan Undang-Undang Dasar 1945.

Setiap kegiatan atau suatu pembangunan yang dilaksanakan di bumi Indonesia ini hendaknya berpedoman pada pembangunan yang berwawasan lingkungan, dan salah satu bagian dari pembangunan nasional Indonesia adalah pembangunan di bidang perumahan. Pembangunan perumahan ini tidak hanya menjadi tanggung jawab pemerintah sematamata, melainkan tanggung jab semua pihak, baik itu masyarakat, pihak swasta atau dalam hal ini disebut Pihak Pengembang dan Real Estate.

Pembangunan perumahan ini menunjukkan bahwa kebutuhan masyarakat akan perumahan dari hari ke hari semakin meningkat sejalan dengan meningkatnya pertambahan penduduk dan meningkatnya pendapatan masyarakat. Tentu saja kebutuhan perumahan yang diinginkan oleh masyarakat itu adalah perumahan yang layak dengan lingkungan yang sehat.

Industri perumahan merupakan industri yang cukup besar perannya dalam pembangunan peekonomian nasional, slain merangkaikan ratusan sektor industri dan jasa, baik di hulu maupun di hilir, nilai sosial industri ini juga tinggi bagi pembangunan kesejahteraan masyarakat. Bahkan pembangunan perumahan dipandang dari perspektif ekonomi sebagai sektor unggulan (leading sector) karena memiliki implikasi luas dalam kegiatan perekonomian baik dilihat dari sifat multiplier effect (efek gandanya) maupun trickle down effect (dampak tetesan kebawahnya).
Pembangunan perumahan ditinjau dari sisi hukum, dimana lebih diorientasikan untuk menjamin kepastian dan ketertiban hukum dalam pembangunan dan pemilikannya. Oleh karena itu pembangunan perumahan haruslah berpedoman pada peraturan hukum yang baerlaku, seperti Undang-Undang Nomor 23 Tahuin 1997 tentang Pengelolaan Lingkungan Hidup, Undang-Undang Nomor 4 Tahun 1992 tentang Perumahan maupun Permukiman maupun peraturan pelaksanaannya. Pelaksanaan pembangunan perumahan dengan berlakunya kedua undang-undang tersebut, berarti setiap kegiatan atau usaha pembangunan perumahan hendaknya memperhatikan pengelolaan lingkungan, sehingga setiap pembangunan perumahan yang mengakibatkan terjadinya perobahan kawasan lingkungan perumahan atau menimbulkan dampak negatif terhadap keadaan lingkungan, maka sejauh mungkin perubahan kawasan dan keadaan tersebut tidak merusak lingkungan, bahkan bagi Pihak Pengembang yang melakukan pembangunan perumahan menjaga keadaan lingkungan menjadi serasi dan seimbang.

Untuk mewujudkan kebutuhan masyarakat akan perumahan terutama di Propinsi Lampung telah dilaksanakan pembangunan perumahan Rumah Sangat Sederhana atau disingkat "RSS Fajar Baru Indah", yang berlokasi di Desa Fajar Baru Kabupaten Lampung Selatan, yang mana lokasi tersebut merupakan daerah pinggiran atau perbatasan dari Kota Bandar Lampung. Pelaksanaan pembangunan perumahan RSS Fajar Baru Indah ini dilaksanakan oleh Pihak Pengembang, yaitu Koperasi Karyawan Pekerjaan Umum Propinsi Lampung atau lebih dikenal dengan sebutan "Kokapu” yang merupakan badan hukum berbentuk koperasi. Perumahan RSS Fajar Baru Indah diperuntukkan bagi karyawan atau Pegawai Negeri Sipil di lingkungan Departemen Pekerjaan Umum Propinsi Lampung, khusunya bagi karyawan atau pegawai 
rendah, seperti; sopir, pegawai di bawah golongan tiga.

Kokapu Propinsi Lampung sebagai Pihak Pengembang yang melaksanakan pembangunan perumahan RSS Fajar Baru Indah hendaknya dalam membangun rumah atau perumahan mengacu pada peraturan hukum yang berlaku. Hal ini ditegaskan dalam Pasal 7 ayat (1) Undang-Undang Nomor 4 Tahun 1992 tentang Perumahan maupun Permukiman menyatakan bahwa : Setiap orang atau badan yang membangun rumah atau perumahan wajib :

a. Mengikuti persyaratan teknis, ekologis, dan administratif;

b. Melakukan pemantauan lingkungan yang terkena dampak berdasarkan rencana pemantauan lingkungan;

c. Melakukan pengelolaan lingkungan berdasarkan rencana pengelolaan lingkungan.

Tingkat kepuasan seseorang untuk membangun atau memiliki perumahan, seperti perumahan RSS Fajar Baru Indah sangatlah tergantung pada kondisi bangunan, status kepemilikan tanah serta sarana dan prasarana lingkungan yang tersedia atau sudah dibangun oleh Pihak Pengembang. Apalagi pembangunan perumahan yang dilakukan oleh Pihak Pengembang Kokapu ini dengan target jumlah rumah sebanyak 224 unit rumah dengan areal lokasi seluas 38.805 $\mathrm{M}^{2}$.

\section{METODE PELAKSANAAN}

Penelitian dilakukan dengan pendekatan secara normatif empiris mengkaji penerapan peratuan perundang-undangan. Sumber datara terdiri data primer dan data sekunder yang didapat melalui studi kepustakaan. Analisa yang dilakukan digunakan dengan diskriptif kualitatif.

\section{HASIL DAN PEMBAHASAN}

\section{A. Pelaksanaan Kewajiban Pihak Pengembang Dalam Pembangunan Perumahan RSS Fajar Baru Indah Lampung Selatan}

Agar pembangunan perumahan seminimal mungkin tidak menimbulkan terganggunya lingkungan hidup, maka pihak pengembang harus mentaati ketentuanketentuan peraturan perundang-undangan yang berlaku yang berhubungan dengan kegiatan pembangunan perumahan. Berdasarkan Pasal 7 ayat (1) menyatakan, bahwa setiap orang atau badan yang membangun rumah atau perumahan wajib:

a. mengikuti persyaratan teknis, ekologis dan administratif;

b. melakukan pemantauan lingkungan yang terkena dampak berdasarkan rencana pemantauan lingkungan;

c. melakukan pengelolaan lingkungan berdasarkan rencana pengelolaan lingkungan.

Berdasarkan target jumlah perumahan yang harus dibangun oleh pihak Pengembang yang seharusnya 224 unit rumah, namun kenyataanya baru terealisasi 139 unit rumah, ini menunjukkan bahwa kokapu selaku perusahaan penbangunan perumahan belum berhasil dan belum profesional dalam pengelolaan perumahan, karena realisasi jumlah target pembangunan perumahan

itu belum terpenuhi. Untuk memenuhi kewajiban secara hukum dalam pelaksanaan pembangunan perumahan RSS Fajar Baru Indah dapat ditinjau dari berbagai aspek sebagai berikut;

\section{Tanah}

Mengenai tanah yang dipergunakan untuk pembangunan perumahan RSS Fajar Baru Indah, terutama areal lokasi tempat dibangunnya perumahan tidak ada permasalahanbaik menganai cara memperoleh hak atas tanah, status kepenilikan. Adapun yang menjadi persoalan adalah tanah jalan transportasi yang menghubungkan lokasi kompleks perumahan menuju jalan poros utama (Jln. RA Basyid) yang panjangnya 45,3 Meter dengan lebar 10 Meter, yang merupakan jalan jalur dua, ternyata lebar jalan tersebut hanya 6 Meter dan pada posisi tengah jalan terdapat tiga tiang listrik, yang mengakibatkan tergangggunya bagi pengendara kendaraan mobil. 


\section{Bangunan Rumah}

Pihak Pengembang atau Kokapu yang membabanguna rumah RSS Fajar Bari Indah adalah rumah dikategorikan rumah yang layak, maksudnya bangunan rumah ini sekurang-kurangnya memenuhi keselamatanan bangunan dan kecukupan minimum luas bangunan, serta kesehatan penghuninya. Bangunan rumah RSS Fajar baru Indah merupalakan type rumah 36, maksud luas fisik bangunan ini adalah $36 \mathrm{M}^{2}$ dengan luas tanah $180 \mathrm{M}^{2}$, serta dilengkapi dengan WC, Sumur bor. Ditinjau dari luas bangunan dan kualitas bangunan RSS fajar baru Indah merupakan rumah yang layak, akan tetapi dari aspek kesehatan belum memenuhi syarat rumah yang layak, karena pembuatanWC secara fisik dibangun dengan ukuran lebar 1 meter, panjang 1 meter. Kedalaman 0,50 meter, sedangkan sumur bor yang merupakan sumber air yang dipergunakan oleh penghuni perumahan untukm kebutuhan sehari-hari seperti, minum, memasak, mencuci tidak berfungsi dan tidak memenuhi syarat kesehatan.

\section{Sarana dan Prasarana Lingkungan}

Merupakan suatu kewajiban pihak Pengembang atau kokapu untuk membangun srana dan prasarana lingkungan perumahan sesuai dengan persyaratan teknis dan ekologis yang telah ditentukan. Adapun kewajiban pihak Pengembang atau kokapu membangun yang berhubungan dengan sarana lingkungan berupa; tempat pendidikan dan bermain, tempat beribadat (Masjid), tempat pelayanan kesehatan(PUSKESMAS) (berdasarkan gambar SITE Plan Kokapu).

Kendatipun sarana lingkungan yang disebutkan di atas sudah ditetapkan dan dicantumkan dalam SITE Plan, namun kenyataannya tempat-tempat tersebut hingga sekarang ini belum dibangun dan yang lebih penting lagi untuk mendapat perhatian baik itu sebagai penghuni warga perumahan maupun pihakm pengembang yaitu tempat pembuangan sampah yang berasal dari unitunit rumah. Hal ini penting karena sampah itu dapat merusak dan mencemari lingkungan sekitar lingkungan perumahan.

\section{B. Alasan Pihak Pengembang Tidak Memenuhi Target Pembangunan Perumahan RSS Fajar Baru Indah Lampung Selatan}

Pembangunan perumahan sejak lama telah terjerat ekonomi biaya tinggi "high cost economy", dengan permintaan dan penawaran akan kebutuhan rumah tidak seimbang. Ekonomi biaya tinggi yang membebani industri perumahan, antara lain disebabkan oleh biaya lahan yang dibebaskan oleh para pengembang, tingginya biaya bunga kredit, proses perizinan yang berbelit tidak efisiensinya, penyediaan material bangunan lokal, serta biaya-biaya siluman. Semua faktor tersebut menyebabkan tingginya biaya produksi yang harus ditanggung oleh pihak Pengembang.

Beban biaya tinggi inilah yang akhirnya harus dibebankan pada harga jual rumah. Di satu sisi, biaya tinggi ini sangat mempengaruhi penentuan harga jual, sedangkan disisi lain tingginya hargas jual justru berakibat pada sebagian besar anggota masyarakat untuk membeli rumah. Ketidak mampuan konsumen perumahan tersebut tidak lain karena peningkatan daya beli sebagian besar masyarakat lebih rendah dibandingkan dengan peninggkatan harga dari tahun ke tahun.

Di samping itu terbatasnya kemampuan pemerintah dan swasta penyediaan rumah sederhana (RS), rumah sangat sederhana (RSS) merupakan kendala tersendiri dalam menciptakan struktur permintaan pasar perumahan yang kuat, berkelanjutan dan efisien. Belum lagi bila ditinjau darei segi profit, dimana pembangunan RS/RSS yang dinilai dari segi keuntungannya terlalu kecil oleh para pengembang Akibat para pengembang lebih banyak mengarahkan sasaran pasarnya pada rumah menengah ke atas. Hal ini karena pangsa perumahan ini lebih banyak memberikan keuntungan.

Akan tetapi yang menjadi permasalahan dalam pembangunan perumahan RSS Fajar Baru Indah Lampung Selatan ini dimana 
pihak Pengembang tidak memenuhi target dalam membangun perumahan tersebut. Adapun yang menjadi alasan-alasan sebagai berikut:

\section{Terbatasnya fasilitas dana KPR BTN yang tersedia}

Dalam pembangunan perumahan RSS

Fajar Baru Indah ini memanfaatkan fasilitas dana KPR BTN sangatlah terbatas, disamping itu juga pihak perbankan PT. (Persero) BTN dalam menyalurkan kredit kepada pihak Pengembang dengan cara selektif dan hatihati dan pihak Pengembang kokapu bukanlah satu-satunya, artinya masih banyak lagi pihak Pengembang perumahan yang harus diperhatikan untuk memperoleh kredit KPR BTN tersbut.

Bagi pihak pengembang kokapu belum memenuhi target pembangunan perumahan berjumlah 224 unit rumah, namun kenyataanya baru terealisasi 139 unit rumah, ini merupakan suatu indikasi bahwa pihak pengembang ini tidak memiliki kredibilitas yang baik. Hal ini didukung pula dimana dari 139 unit rumah yang sudah ada pemilik tersebut, hingga saat sekarang baru 78 unit rumah yang dilengkapi dengan fasilitas listrik.

\section{Tidak tersedianya modal yang dimiliki oleh pihak Pengembang Kokapu}

Pihak pengembang kokapu sebagai badan usaha yang berbentuk koperasi, dimana modal yang dimilikinya sangatlah terbatas dari simpanan pokok anggota koperasi karyawan PU Propinsi Lampung. Sedangkan dalam kegiatan pembangunan perumahan diperlukan modal cukup besar. Memang pihak Pengembang kokapu pernah mendapat fasilitas kredit KPR BTN, tetapi pada pelaksanaan pemanfaatan dana tersebut tidak tepat. Hal ini terbukti belum dilengkapinya fasilitas dan sarana lingkungan seperti; listrik, tempat peribadatan, tempat bermain dan olahraga serta sarana jalan transportasi menuju perumahan yang seharusnya jalan dengan dua jalur, yang lebarnya 10 meter, tetapi yang dibangun hanya lebar jalan 6 meter. Hal ini dikarenakan pembelian lahan tanah untuk jalan tersebut belum dilunasi oleh pihak Pengembang kokapu, sehingga pemilik tanah tidak bersedia menyerahkan tanahnya. Dengan demikian sudah jelas pihak Pengembang kokapu tidak dapat memenuhi target pembangunan perumahan.

\section{Rendahnya calon peminat pembeli perumahan RSS Fajar Baru Indah}

Memang kebutuhan masyarakat akan perumahan terus meningkat seiring dengan tuntutan pertambahan penduduk yang terus bertambah. RSS Fajar Baru Indah terletak di daerah pinggiran Kota Bandar Lampung yng disebabkan fasilitras dan sarana lingkungan perumahan belum terbangun, kemudian setiap unit rumah belumlah dilengkapi dengan fasilitas rumah yang layak, sehat dan rapi, seperti belum terpasangnya fasilitas listerik, sumber air berupa sumur bor yang tidak berfungsi serta WC yang dibuat tidak memenuhi sandar sanitasi dan sebagainya. Selain itu pula sarana transportasi yang digunakan untuk menuju ke perumhan RSS Fajar Baru Indah belum tersedia seperti angkutan umum, yang ada sarana transportasi berupa ojek dan becak, sehingga beban biaya pengeluaran yang haruis dikeluarkan bagi masyarakat yang tingggal di perumahan tersebut menjadi tinggi bila tidak mmiliki kendaraan bermotor; mobil atau motor, sedangkan kebnayakan warga perumahan $\mathrm{Pu}$ menggantungkan pekerjaan di daerah perkotaan.

\section{Manfaat Pembangunan Perumahan RSS Fajar Baru Indah Bagi Masyarakat Desa Fajar Baru Lampung Selatan}

Seperti kita ketaui bahwa setiap kegiatan pembangunan di sektor perumahan ini dapat menimbulkan dampak baik itu dampak negatif maupun dampak positif . dampak negatif pembangunan perumahan RRS Fajar baru indah ini berupa pengaruh yang dapat merugikan lingkungan alam dan sekitarnya yang dirasakan oleh di sekitar masyarakat desa Fajar Baru sangatlah kecil sekali, namun dampak positif yang di rasakan oleh masyarakat berupa pengaruh terhadap kehidupan manusia dan hubungannya dengan 
lingkungan alam di sekitarnya yang dapat menguntungkan dapat dirasakan oleh masyarakat.

Begitu juga, mulai dari pembangunan awal perumahan RSS fajar baru snpai saat sekarang, salah satu danpak positif yang lain adalah membuka kesempatan bagi masyarakat untuk bekerja dan berusaha di sektor perumahan . karena masyarakat desa Fajar Baru disamping pekerjaan utamanya sebagai petani, mereka ini dapat bekerja sebagai buruh atau sebagai tukang bangunan perumahan, ini berarti dengan adanya perumahan tersebut buruh atau tukang bangunan bekerja baik untuk membngun unit rumah maupun memperbaiki rumah yang sudah terbangun, yang berarti pula memberikan peluangdan kesempatan bagi masyarakat.

Dampak positif pembangunan perumahan RSS Fajar Baru indah yang dapat di rasakan bagi masyararakat desa Fajar Baru yaitu dalam kehidupan sosial masyarakat. Dimana hubungan antara masyarakat penghuni perumahan dengan warga masyarakat desa Fajar Baru telah terjalin hubungan yang harmonis. Ini terlihat dari sikap perilaku masyarakat dalam melakukan kegiatan gotong royong dalam pembersihan lingkungan desa, ataupun secara bersama melakukan kegiatan keagamaan, seperti memperingati hari isra' mi 'raj, memperingati maulid nabi Muhammad SAW, melaksanakan hari raya Idul fitri dan Idul adha , maupun kegiatan hari besar nasional lainnya, seperti memperingati hari proklamasi Kemerdekaan Republik Indonesia yang dilaksanakan setiap tahunya dengan membentuk kepanitian bersama . Hal ini dilakukan hanyalah semata-mata untuk menciptakan kondisi hubungan antara masyarakat desa Fajar Baru semakin erat.

Adapun bentuk lain partisipasi warga perumahan RSS Fajar Baru Indah terhadap kehidupan sosial, yaitu dimana secara bersama dendan cara gotong royong kembali perluasan tanah makam bagi penduduk masyarakat desa fajar baru. Begitu pula pembangunan perumahan RSS Fajar Baru Indah ini mempunyai aspek danpak sosial budaya bagi masyarakat di sekitarnya .Berbicara mengenal dampak sosial budaya dapat berpengaruh terhadap aktivitas kehidupan masyarakat, karena memang budaya masyarakat disini yang mayoritas penduduknya tergolong suku jawa dan sunda, tentunya kehidupan sosial masyarakat warga perumahan RSS Fajar Baru Indah harus menyesuaikan dengan budaya yang sudah turun-temurun dianut dan diakui, dihormati oleh masyarakat setempat. Hal ini terbukti dalam kegiatan upacara perkawinan, ataupun persedekahan sunatan, upacara kehamilan dan sebagainya.

Demikian pula danpak positif pembangunan perumahan terhadap lingkungan hidup, misalnya terkendalinya hama dan penyakit, tersediany air bersih terkendalinya banjir, dan lain-lain. Untuk dampak positif terhadap hidup, seperti air bersih yang dipergunakan baik oleh masyarakat perumahan RSS Fajar Baru Indah maupun warga di sekitarnya dimana sumber air bersih bersumber atau diperoleh dari sumur bir atau sumur biasa, sedangkan sumber air yang berasal dari aliran sungai Way Reda hanya dipergunakan untuk kepentingan pertanian, pertenakan hewan saja, apabila pada saat musim kemarau aliran sungai itupun menjadi surut.

Dampak positif pembangunan terhadap lingkungan hidup di kawasan perumahan RSS Fajar Baru Indah dari bahaya banjir atau pencemaran lingkungan sedikit sekali muncul, karena lokasi tsnsh ysng dipergunakan bagi pembangunan perumahan itu merupakan lokasi yang letaknya diatas permukaan sungai way reda, sehingga pembuangan air kotoran yang berasal dari rumah tangga langsung di salurkan melalui got-got atau saluran yang menuju ke aliran sungai, ini berarti pencemaran lingkungan hampir tidak ada .

Tetapi dengan kependapatan penduduk semakin meningkat, dan tidak adanya lokasi tempat pembuangan sampah bagi warga perumaha RSS Fajar Baru Indah, sehingga sampah-sampah yang dihasilkan oleh unitunit rumah tangga dibuang secara sembarangan dipinggir kali alairan sungai 
Way Reda, yang kesemuanya itu dapat menimbulkan bau dan penyakit. Dengan demikian berarti dampak positif dari pembangunan perumahan RSS Fajar Baru Indah lebih banyak dimanfaatkan bagi masyarakat sekitarnya, baik untuk kegiatan ekonomi, memberikan kesempatan dan peluang kerja bagi masyarakat, sehingga menjadi sumber penghidupan dan penghasilan bagi kesejahteraan keluarga.

\section{KESIMPULAN DAN SARAN}

Pelaksanaan kewajiban pihak Pengembang dalam pembangunan perumahan RSS Fajar Baru Indah adalah Pihak Pengembang telah membangun unitunit rumah berjumlah 139 unit rumah yang sudah dilengkapi sarana seperti WC, sumur bor, tetapi sarana tersebut belum memenuhi persyaratan teknis dan ekologis yang ditentukan oleh ketentuan hukum yang berlaku, belum melaksanakan kewajibannya melakukan pembangunan fasilitas dan sarana umum seperti tempat bermain, tempat beribadat dan berolahraga.

Alasan pihak Pengembang tidak memenuhi target pembangunan perumahan RSS Fajar Baru Indah Lampunbg Selatan dikarenan : terbatasnya fasilitas dana KPR BTN yang tersedia, tidask tersedianya modal yang dimiliki oleh pihak Pengembang Kokapu, rendahnya calon peminat pembeli perumahan RSS Fajar Baru Indah. Manfaat pembangunan perumahan RSS Fajar Baru Indah bagi masyarakat Desa Fajar Baru Lampung Selatan, yaitu menimbulkan dampak positif yang merupakan manfaat dan keuntungan bagi kehidupan sosial, ekonomi dan budaya..

\section{DAFTAR PUSTAKA}

Blaang, C. Djemabut. 1986. "Pokok-Pokok Kebijaksanaan Perumahan dan Permukiman" Jakarta: Yayasan Obor Indonesia.

Franklin, Richard. 2000. Kompas Harian Umum "Perkembangan Restrukturisasi Sektor Perumahan di BPPN". Jakarta.
Hamzah, A,. 1987 "Penegakan Hukum Lingkungan", Jakarta: CV. Santa Artha Jaya.

Hardjasoemantri, Koesnadi, "Hukum Tata Lingkungan”, Yogyakarta: Gajahmada University Press. Yogyakarta.

------. " "Environmental Legislation Indonesia”. Gajahmada University Press. Yogyakarta.

P. Soemartono, R.M. Gatot. 1996. "Hukum Lingkungan Indonesia”. Sinar Grafika. Jakarta.

Purnadi, Purbacaraka. Soerjono Soekanto. 1992. "Sendi-Sendi Ilmu Hukum dan Tata Hukum". Penerbit Alumni. Bandung.

Reksohadiprojo, Soekanto.A.R. Karseno. 1997. “Ekonomi Perkotaan”. BBPFE. Yogyakarta.

Suparni, Niniek. 1992. "Pelestarian, Pengelolaan dan Penegakan Hukum Lingkungan”. Sinar Grafika. Jakarta.

Soemarwoto, Otto. 1981. “Analisis Dampak Lingkungan”. Gajahmada University Press. Yogyakarta. 